\title{
EFEKTIVITAS PEMBELAJARAN DENGAN MENGGUNAKAN MEDIA ANIMASI TERHADAP PEMAHAMAN KONSEP FISIKA SISWA KELAS X SMAN 3 PINRANG
}

\author{
Imam Permana ${ }^{1}$, Ansarullah $^{2}$, Fitriani Kadir ${ }^{3}$ \\ UIN Alauddin Makassar, UIN Alauddin Makassar, Universitas Muslim Maros \\ imam.permana922@gmail.com
}

\begin{abstract}
The Effectiveness of Learning Using Animated Media on Students' Understanding of Physics Concepts Class X SMAN 3 Pinrang. This study aims to determine the influence of Macromedia Flash animation media on increasing physics concept understanding of students SMAN 3 Pinrang. This research is a Quasi Experiment with The Matching Postest Only Control Group Design. The population consisted of 4 classes and 2 classes were taken as the control and experimental class. The instrument used was a concept understanding test and a student response questionnaire. The data analysis technique used is descriptive and inferential with each instrument is analyzed after being validated by an expert. The results showed that there was a difference in the cencept understanding of the experimental class and the control class where the average post-test score of the Experiment class was 62.38, while the control class was 45.43. Inferential analysis shows $t_{\text {count }}=3.87$ and $t_{\text {table }}=2.04$. Based on the provisions, $\left(t_{\text {count }}>t_{\text {table }}\right)$. It can be said that $\mathrm{H}_{1}$ is accepted, concluded that there are differences in physics concept understanding of students who are taught using animation media with students who are not taught using animation media in class X SMAN 3 Pinrang.
\end{abstract}

Keywords: animation media, understanding physics concepts

\begin{abstract}
Abstrak: Efektivitas Pembelajaran dengan Menggunakan Media Animasi terhadap Pemahaman Konsep Fisika Siswa Kelas X SMAN 3 Pinrang. Penelitian ini bertujuan untuk mengetahui besarnya pengaruh penggunaan media animasi Macromedia Flash terhadap peningkatan pemahaman konsep peserta didik kelas X SMAN 3 Pinrang. Jenis penelitian ini adalah Quasi Eksperimen dengan desain The Matching Postest Only Control Group Design. Populasi dari penelitian tersebut sebanyak 4 kelas dan diambil 2 kelas sebagai kelas kontrol dan eksperimen dengan tehnik Matching Sampling. Instrumen yang digunakan adalah tes pemahaman konsep dan angket respon siswa. Teknik analisis data yang digunakan adalah teknik analisis deskriptif dan inferensial serta setiap instrumen dianalisis setelah divalidasi oleh pakar. Hasil penilitian menunjukkan adanya perbedaan pemahaman konsep kelas eksperimen dan kelas kontrol di mana skor rata-rata post test kelas Eksperimen sebesar 62,38 sedangkan pada kelas kontrol 45,43. Analisis inferensial menunjukkan nilai $t_{\text {hitung }}=3,87$ dan $t_{\text {tabel }}=2,04$.
\end{abstract}


Berdasarkan ketentuan, $t_{\text {hitung }}$ lebih besar dari pada $t_{\text {tabel }}\left(t_{\text {hitung }}>t_{\text {tabel }}\right)$ yaitu $(3,87>2,04)$. Dari data tersebut dapat dikatakan $H_{0}$ ditolak dan $H_{1}$ diterima, dengan demikian dapat disimpulkan bahwa Terdapat perbedaan pemahaman konsep fisika siswa yang diajar dengan menggunakan media animasi dengan siswa yang tidak diajar dengan menggunakan media animasi pada kelas X SMAN 3 Pinrang.

Kata kunci: media animasi, pemahaman konsep fisika

Pendidikan bagi kehidupan manusia di muka bumi merupakan kebutuhan mutlak yang harus dipenuhi sepanjang hayat. Tanpa pendidikan mustahil suatu kelompok manusia dapat hidup berkembang sejalan aspirasi (citacita) untuk maju, sejahtera, dan bahagia.

Dalam pendidikan kita mengenal istilah belajar dan pembelajaran. Belajar merupakan tindakan dan perilaku siswa yang kompleks sebagai tindakan, maka belajar hanya dialami oleh siswa sendiri. Menurut Gagne dan Briggs mendefinisikan istilah pembelajaran sebagai suatu rangkaian events (kejadian, peristiwa, keadaan,dan sebagainya) yang secara sengaja dirancang untuk mempengaruhi pelajar sehingga proses belajarnya dapat berlangsung dengan mudah.

Berdasarkan Undang-Undang Republik Indonesia Nomor 20 Tahun 2003 tentang sistem pendidikan nasional menyatakan bahwa pendidikan adalah usaha sadar dan terencana untuk mewujudkan suasana belajar dan proses pembelajaran agar peserta didik secara aktif mengembangkan potensi dirinya untuk memiliki kekuatan spiritual kegamaan, pengendalian diri, kepribadian, kecerdasan, akhlak muliah, serta keterampilan yang diperlukan dirinya, masyrakat, bangsa dan negara.

Salah satu cabang dari Ilmu Pengetahuan Alam (IPA) adalah ilmu fisika yang merupakan ilmu yang mempelajari fenomena alam. Ilmu fisika merupakan dasar dari sains adalah ilmu yang diperoleh berdasarkan pengamatan dan eksperimen, serta menghubungkan kenyataankenyataan berdasarkan metode ilmiah sehingga keberadaannya sangat penting bagi perkembangan ilmu pengetahuan dan tehnologi.

Salah satu hal yang membuat siswa menganggap fisika sebagai pelajaran yang membosankan karena fisika adalah pelajaran yang hanya menuliskan angka-angka dan menghitungnya berdasarkan rumus yang telah diajarkan guru. Selain itu, kebanyakan guru mengajar fisika dengan metode yang monoton seperti memberikan rumus, kemudian contoh soal tanpa disertai visualisasi yang bisa membantu siswa dalam menalari konsep yang diajarkan.

Hamalik (1996) dalam Arsyad (2011 : 15) menyatakan bahwa pemakaian media pembelajaran dalam proses pembelajaran dapat membangkitkan keinginan dan minat yang baru, membangkitkan motivasi dan rangsangan kegiatan belajar, dan bahkan membawa pengaruh-pengaruh psikologi terhadap siswa.

Salah satu media animasi yang dapat digunakan sebagai media pembelajaran adalah media animasi berbasis Macromedia Flash. Kelebihan Macromedia Flash yaitu merupakan teknologi animasi web yang paling popular saat ini sehingga banyak didukung oleh berbagai pihak, ukuran file yang kecil dengan kualitas yang baik, keutuhan Hardware yang tidak tinggi, dapat membuat website, cd-interaktif, animasi web (Sakti,dkk 2012: 2).

Penelitian yang dilakukan oleh Sigit, dkk (2012) dengan judul : "Keefektifan Penggunaan Media Animasi Macromedia Flash pada Materi Kompresor" menunjukkan bahwa peningkatan tanpa menggunakan media animasi macromedia flash sebesar 54,14\% sedangkan yang menggunakan media animasi macromedia flash sebesar 113\% dalam materi kompresor pada mahasiswa pendidikan teknik mesin).

Peneliti menganggap penerapan media animasi ini sesuai dengan proses 
Karst : Jurnal Pendidikan Fisika dan Terapannya

Volume 3 | Nomor 2 | 48

p-ISSN: 2622-9641 e-ISSN: 2655-1276

pembelajaran fisika, karena dalam pembelajaran menggunakan media animasi dapat menggali potensi siswa untuk berpartisipasi aktif dalam proses pembelajaran karena adanya media animasi flash dimana dalam media animasi itu terdapat kumpulan gambar yang diolah sedemikian rupa sehingga menghasilkan gerakan. Untuk itu, peneliti tertarik melakukan penelitian dengan judul "Efektivitas Pembelajaran Dengan Menggunakan Media Animasi Terhadap Pemahaman Konsep Fisika Siswa Kelas X SMAN 3 Pinrang".

Penelitian ini bertujuan untuk mengetahui perbedaan pemahaman konsep fisika antara peserta didik yang diajar dengan menggunakan media animasi pembelajaran dengan siswa yang tidak diajar dengan menggunakan media animasi pembelajaran pada kelas $\mathrm{X}$ SMAN 3 Pinrang.

\section{METODE}

Jenis penelitian ini adalah quasi eksperimen di mana peneliti langsung mengambil dua kelas sampel secara langsung yang sudah terbentuk dalam kelompok yang utuh atau peneliti tidak melakukan pengambilan secara random.

Desain penelitian ini adalah (The Matching Postest Only Control Group Design) digambarkan oleh Frankel dan Wallen (1977:271) sebagai berikut :

\begin{tabular}{llll|}
\hline Treatment group & $\mathbf{M}_{1}$ & $\mathbf{X}$ & $\mathbf{O}_{\mathbf{1}}$ \\
\cline { 2 - 4 } Control group & $\mathbf{M}_{\mathbf{2}}$ & $\mathbf{C}$ & $\mathbf{O}_{\mathbf{2}}$ \\
\hline $\begin{array}{l}\text { Keterangan : } \\
\mathrm{M}_{1} \& \mathrm{M}_{2}: \text { Macthing sampel (pemasangan sampel) } \\
\mathrm{X} \quad \text { : Treatment meggunakan media } \\
\text { Animasi pembelajaran }\end{array}$ \\
$\mathrm{C} \quad$ : Treatment dengan pembelajaran \\
$\mathrm{O}_{1} \& \mathrm{O}_{2}:$ Pemberian tes setelah perlakuan
\end{tabular}

Populasi dalam penelitian ini adalah semua siswa kelas X SMAN 3 Pinrang tahun ajaran 2019/2020, yang terdiri dari empat kelas dengan jumlah siswa 124 orang.

Pengambilan sampel dengan random class dilakukan melalui tekhnik macthing, yaitu penyetaraan atau pemasangan sampel dengan langkah sebagai berikut:

1. Dua kelas pada populasi yang memiliki nilai pre-test yang sama diambil sebagai sampel.

2. Dua kelas tersebut kemudian ditetapkan sebagai kelas kontrol dan kelas eksperimen.

3. Mengambil sampel dengan jumlah yang sama pada masing-masing kelas dengan mencocokkan nilai pre-test.

Dari teknik di atas, maka didapatkan distribusi pengambilan sampel yang dapat dilihat pada tabel 1:

Tabel 1. Distribusi Sampel

\begin{tabular}{|c|c|c|c|c|c|}
\hline \multirow{2}{*}{ No } & \multirow{2}{*}{ Kelas } & \multicolumn{2}{|c|}{ Jenis kelamin } & \multirow{2}{*}{ Jumlah } & \multirow{2}{*}{ Sampel } \\
\hline & & $\mathrm{L}$ & $\mathrm{P}$ & & \\
\hline 1 & X IPA 1 & 13 & 21 & 34 & 15 \\
\hline 2 & X IPA 2 & 8 & 21 & 29 & 15 \\
\hline 3 & X IPA 3 & 11 & 20 & 31 & 0 \\
\hline 4 & X IPA 4 & 12 & 18 & 30 & 0 \\
\hline \multicolumn{2}{|c|}{ Jumlah } & 44 & 80 & 124 & 30 \\
\hline
\end{tabular}


Instrumen yang digunakan adalah tes pemahaman konsep fisika sebagai instrumen utama dan angket keterlaksanaan pembelajaran dengan Direct Intructions berbasis media animasi Macromedia Flash.

Proses pengumpulan data dapat dilihat pada gambar 1:

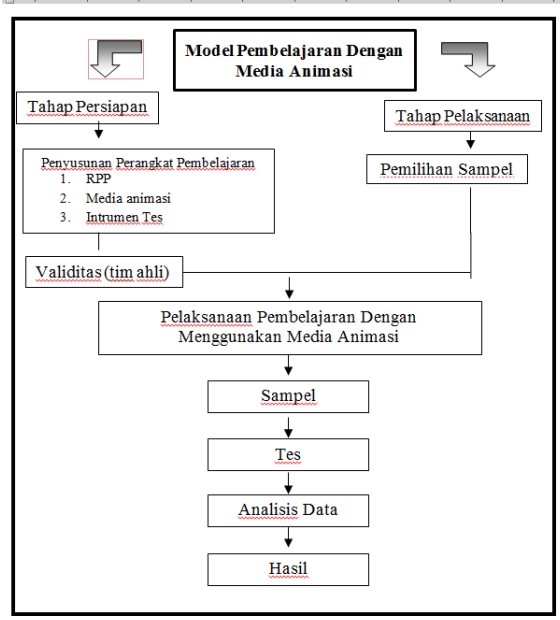

Gambar 1 proses pengumpulan data
Teknik analisis data yang digunakan adalah analisis deskriptif dan analisis inferensial pada taraf signifikansi 5\%. Digunakan pula program IBM SPSS versi 20 for Windows untuk menguji hipotesis sebagai teknik analisis pendukung.

\section{HASIL DAN PEMBAHASAN}

Pada analisis deskrptif dilakukan analisis Gain yaitu analisis gabungan antara nilai pre test dan post test untuk kelas eksperimen dan kelas kontrol. Adapun hasil analisisnya dapat dilihat pada tabel 2.

Tabel 2. Statistik gain pemahaman konsep fisika kelas eksperimen dan kelas kontrol

\begin{tabular}{lcc}
\hline \multicolumn{1}{c}{ Statistik Gain } & Kelas Eksperimen & Kelas Kontrol \\
\hline Skor maksimum $\bar{d}$ & 88 & 60 \\
Skor minimum $\bar{d}$ & 7 & 7 \\
Rata-rata $\bar{d}$ & 35,64 & 18,69 \\
Standar deviasi $\bar{d}$ & 12,557 & 11,74 \\
Varians $\bar{d}$ & 157,67 & 137,94 \\
\hline
\end{tabular}

Berdasarkan tabel 2 terlihat bahwa, skor maksimun untuk analisis gain pada kelas eksperimen yaitu 88 sedangkan pada kelas kontrol yaitu 60 , dan skor minimun pada kelas eksperimen yaitu 7 sedangkan pada kelas kontrol yaitu dengan nilai 7 dan nilai rata-rata pada kelas kontrol 18,69 dan standar deviasi 11,74. Sedangkan nilai rata-rata pada kelas eksperimen 35,64 sehingga diperoleh standar deviasi 12,55. Pada tabel 4.24 juga diperoleh nilai variasi untuk kelas eksperimen 150,97 sedangkan pada kelas kontrol 137,94.

Analisis inferensial yang pertama dilakukan adalah uji normalitas dimana uji normalitas untuk gain dapat dilihat pada tabel 3 .

Tabel 3. Uji normalitas pemahaman konsep fisika secara manual pada gain

\begin{tabular}{ccccc}
\hline & Kelas & $D_{\text {Hitung }}$ & & $D_{\text {Tabel }}$ \\
\hline \multirow{2}{*}{ Gain } & Kelas Eksperimen & 0,113 & 0,338 & \\
& Kelas Kontrol & 0,153 & 0,338 & \\
\hline
\end{tabular}


Karst : Jurnal Pendidikan Fisika dan Terapannya

Volume 3 | Nomor 2 | 50

p-ISSN: 2622-9641 e-ISSN: 2655-1276

Tabel 3 menunjukkan nilai gain pada kelas eksperimen untuk $\mathrm{D}_{\text {Hitung }}$ sebesar 0,113 dan kelas kontrol 0,153, kedua nilai $\mathrm{D}_{\text {Hitung }}$ tersebut lebih kecil dari pada $\mathrm{D}_{\text {Tabel }}$ sehingga skor untuk kelas eksperimen dan skor untuk kelas kontrol sama-sama berdistribusi normal.

Hasil ini sejalan dengan hasil yang diperolah melalui hasil SPSS versi 20 for Windows dapat dilihat pada tabel 4

Tabel 4. Uji normalitas gain pemahaman konsep fisika menggunakan program SPSS versi 20 for Windows untuk kelas eksperimen dan kelas kontrol

\begin{tabular}{llllllll}
\hline \multirow{2}{*}{ KELAS } & \multicolumn{9}{l}{ Tests of Normality } \\
\cline { 2 - 8 } & Kolmogorov-Smirnov & \multicolumn{2}{l}{ Shapiro-Wilk } \\
\hline Statistic & Df & Sig. & Statistic & Df & Sig. \\
\hline K. Eksperimen &, 154 & 15 &, $200^{*}$ &, 939 & 15 &, 366 \\
\hline K. Kontrol &, 198 & 15 &, 117 &, 882 & 15 &, 051 \\
\hline
\end{tabular}

Tabel 4 menunjukkan data kelas eksperimen yang diterapkan dengan menggunakan model pembelajaran Direct Instruction berbasis media media Macromedia Flash dan kelas kontrol dengan model pembelajaran Direct Instruction yang terdistribusi normal. Hal ini dapat dilihat dari nilai signifikan untuk Kelas Eksperimen baik dengan menggunkan model Kolmogorov Smirnov diperoleh nilai signifikan sebesar 0,200 lebih besar dari 0,05 (sig. > 0,05) maupun dengan model Shapiro-Wilk diperoleh nilai signifikan sebesar 0,366 lebih besar dari 0,05 (sig. > 0,05) Maka dapat disimpulkan bahwa data tersebut berdistribusi normal, dan untuk kelas kontrol diperoleh nilai signifikan untuk model Kolmogorov - Smirnov sebesar 0,117 lebih besar dari 0,05 (sig. > 0,05) maupun dengan model Shapiro-Wilk diperoleh nilai signifikan sebesar 0,051 lebih besar dari 0,050 (sig. > 0,05) Maka dapat disimpulkan bahwa data tersebut berdistribusi normal.

Untuk memperkuat kesimpulan di atas, data hasil tes pemahaman konsep dibuat dalam bentuk diagram normal QQ Plot untuk kelas eksperimen dan kelas kontrol. Digram QQ Plot terlihat mengikuti fit line, maka data tersebut berdistribusi normal. Begitu pula halnya pada detrend QQ plot yang menunjukkan plot-plot tersebar merata baik di atas maupun di bawah garis horizontal, maka dapat disimpulkan data berdistribusi normal. Hasil analisis data normalitas dapat dilihat seperti gambar 2 .
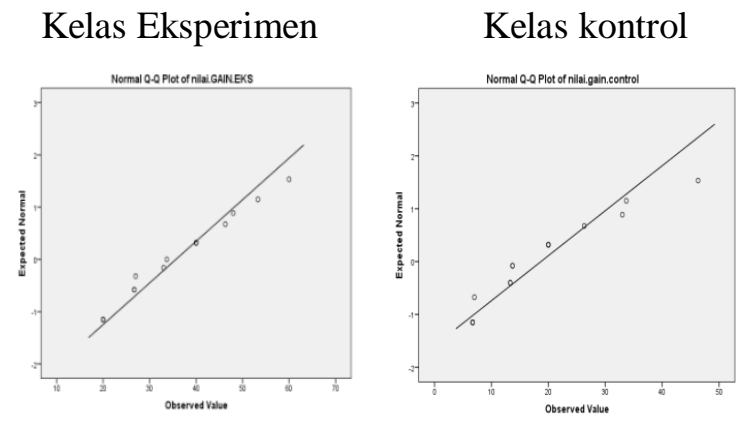

Gambar 2 Normal QQ plot untuk kelas eksperimen dan kelas kontrol

Dari analisis uji hipotesis diperoleh nilai $t_{\text {hitung }}$ $=3,87$ dan $\mathrm{t}_{\text {table }}=2,04$ pada taraf signifikan $\alpha=$ 0,05, sehingga disimpulkan. Bahwa $\mathrm{t}_{\text {hitung }}>\mathrm{t}$ table Hal ini menunjukkan bahwa $\mathrm{H}_{\mathrm{O}}$ ditolak dan $\mathrm{H}_{\mathrm{a}}$ diterima, karena secara keseluruhan terdapat perbedaan yang signifikan antara kelas eksperimen dengan model pembelajaran Direct Instruction. berbasis media animasi Macromedia Flash dan kelas kontrol dengan pembelajaran Direct Instruction .

\section{PEMBAHASAN}

Pemahaman konsep fisika yang diajar dengan model pembelajaran Direct Instruction berbasis media animasi macromedia Flash.

Salah satu variabel dalam penelitian ini adalah pemahaman konsep fisika yang diukur dengan menggunakan instrumen tes yang terdiri dari 30 soal dimana pre testnya 15 soal dan post testnya 15 soal pilihan ganda pada kelas X IPA 2 SMAN 3 Pinrang. 
Analisis data hasil tes sebelum penerapan model pembelajaran Direct Instruction berbasis media animasi Macromedia Flash memberikan gambaran berupa skor pemahaman konsep berada pada rata-rata sebesar 26,74 dengan berada pada kategorisasi sangat rendah dengan persentase sebesar 93,3\%, dan setelah diterapkan model pembelajaran Direct Instruction berbasis media animasi Macromedia Flash skor pemahaman konsep berada pada rata-rata 62,38 dengan kategorisasi t rendah dengan presentase sebesar 60,00 \%. Sehingga dari rata-rata dan kategorisasi tersebut kita dapat menyimpulkan bahwa telah ada peningkatan pemahaman konsep fisika setelah diterapkan model pembelajaran Direct Instruction berbasis media animasi Macromedia Flash pada kelas X IPA 2.

Hal ini diperkuat oleh Penelitian yang dilakukan oleh Sigit, dkk (2012) dengan judul : "Keefektifan Penggunaan Media Animasi Macromedia Flash pada Materi Kompresor" menunjukkan bahwa peningkatan tanpa menggunakan media animasi macromedia flash sebesar 54,14\% sedangkan yang menggunakan media animasi macromedia flash sebesar $113 \%$ dalam materi kompresor pada mahasiswa pendidikan teknik mesin).

Selain data diatas peneliti juga menggunakan instrumen pendukung yaitu angket respon siswa untuk melihat seberapa besar pengaruhnya media animasi Macromedia Flash yang digunakan pada proses pembelajaran pada kelas eksperimen X IPA 2. Setelah dinalisis hasil keseluruhan aspek-aspek pernyataan pada angket didapatnya nilai rata-rata dari 15 siswa yaitu sebesar 4,38 hal ini menunjukkan bahwa mereka sangat merespon adanya penggunaan media animasi Macromedia Flash karena ditinjau dari kegunaaan atau fungsi media animasi kemudian dikaitkan dengan pertanyaan pada lembar respon siswa, media animasi Macromedia Flash mampu membuat mereka mudah memahami materi yang diajarkan karena sesuatu yang terkadang sulit untuk mereka pahami menjadi mudah ketika suatu konsep fisika dijelaskan dengan menggunakan media animasi Macromedia Flash. Berkaitan dalam proses belajarnya sangat ada perbedaan ketika menggunakan media animasi dengan yang tidak menggunakan yaitu siswa lebih aktif bertanya ketika ada yang mereka tidak pahami dari animasi yang di tampilkan yang berkaiatan dengan materi serta perhatian siswa ternyata lebih terfokus kepada materi yang diajarkan kemudian selain itu media animasi ini pula merupakan hal baru bagi mereka sehingga pengaruhnya sangat besar dalam meningkatkan semangat belajar siswa dan pada akhirnya tujuan dari pembelajaran dapat tercapai sesuai dengan KKM yang telah ditetapkan. Lain halnya ketika tanpa media atau hanya menggunakan pembelajaran langsung biasanya siswa atau peserta didik kurang menanggapi materi yang disampaikan serta siswa cepat merasa bosa dikarenakan rata-rata guru mengguakan model pembelajaran langsung saat mengajar dikelas.

\section{Pemahaman konsep fisika yang diajar dengan model pembelajaran Direct Instruction tanpa media animasi Macromedia Flash.}

Variabel lain dari penelitian ini adalah pemahaman konsep fisika yang diukur dengan menggunakan instrumen tes yang terdiri dari 30 soal pilihan ganda dimana Pretestnya 15 soal dan Posttestnya 15 soal pada kelas X IPA 1 SMAN 1 Pinrang .

Analisis data hasil tes sebelum penerapan model pembelajaran Direct Instruction memberikan gambaran berupa skor pemahaman konsep berada pada rata-rata sebesar 26,74 dengan berada pada kategorisasi sangat rendah dengan persentase sebesar $93,33 \%$, dan setelah diterapkan model pembelajaran Direct Instruction tanpa media animasi skor pemahaman konsep berada pada rata-rata 45,43 dengan kategorisasi sangat rendah dengan presentase sebesar 73,3\%. Sehingga dari ratarata dan kategorisasi tersebut kita dapat menyimpulkan bahwa dari rata-rata telah ada peningkatan pemahaman konsep fisika setelah diterapkan model pembelajaran Direct Instruction pada kelas X IPA 1 namun hanya sedikit terjadi peningkatan sebelum dan sesudah diberikan perlakuan.

Dari pembahasan diatas kita dapat melihat bahwa penerapan antara model pembelajaran Direct Instruction berbasis media animasi Macromedia Flash dan penerapan model pembelajaran Direct Instruction tanpa media Macromedia Flash pada kelas yang berbeda yaitu kelas X IPA 1 dan X IPA 2 memiliki 
Karst : Jurnal Pendidikan Fisika dan Terapannya Volume 3 | Nomor 2 | 52 p-ISSN: 2622-9641 e-ISSN: 2655-1276

perbedaan, hal ini dapat dilihat pada nilai ratarata setelah masing-masing kedua kelas tersebut diberikan perlakuan yaitu pada kelas eksperimen (X IPA 2) dengan rata-rata 61,58 dan untuk kelas kontrol (X IPA 1) dengan rata-rata 45,43. Hal tersebut juga dapat dilihat pada saat dilakukan analisis gain dimana pada kelas eksperimen diperoleh nilai rata-rata sebesar 35,64 dan pada kelas kontrol 18,69.

Hal ini terbukti setelah dilakukan uji hipotesis, Berdasarkan hasil perhitungan diperoleh nilai $\mathrm{t}_{\text {hitung }}=3,87$ dan $\mathrm{t}$ table $=2,04$ pada taraf signifikan $\alpha=0,05$, sehingga disimpulkan. Bahwa $\mathrm{t}$ hitung $>\mathrm{t}$ table. Hal ini menunjukkan bahwa $\mathrm{H}_{\mathrm{O}}$ ditolak dan $\mathrm{H}_{\mathrm{a}}$ diterima, karena secara keseluruhan terdapat perbedaan yang signifikan antara kelas eksperimen dengan model pembelajaran Direct Instruction berbasis media animasi Macromedia Flash dan kelas kontrol dengan pembelajaran Direct Instruction . Sehingga secara keseluruhan terdapat perbedaan yang signifikan antara kelas eksperimen dengan model pembelajaran Direct Instruction berbasis media animasi Macromedia Flash dan kelas kontrol dengan model pembelajaran Direct Instruction.

\section{DAFTAR PUSTAKA}

Arikunto, S. 2010. Prosedur Penelitian: Suatu Pendekatan Praktik. (Edisi Revisi). Jakarta : Rineka Cipta.

Arsyad, Azhar. 2011. Media pembelajaran. Jakarta : PT Grafindo

Bloom, Benyamin S. 1975. Taxonomi Of Educational Objective. Dalam Supriyono. 2010. Cooperative Learning. Yogyakarta: Pustaka Belajar.

Darmawan, deni. 2012. Teknologi Pembelajaran. Bandung: PT Remaja Rosdakarya.

Depdiknas. 2005. Materi Pelatihan Terintegrasi Ilmu Pengetahuan Alam. Jakarta: Depdiknas.

Hamid Darmadi. (2012). Metode Penelitian Pendidikan dan Sosial. Pontianak. Penerbit Alfabeta $C V$.

\section{PENUTUP}

Hasil penelitian menunjukkan bahwa terdapat perbedaan pemahaman konsep fisika antara peserta didik dalam mata pelajaran fisika yang diajar dengan model pembelajaran Direct Intruction berbasis media animasi Macromedia Flash pada kelas X IPA 2 dan peserta didik yang diajar tanpa animasi Macromedia Flash pada kelas X IPA 1 SMAN 3 Pinrang. Hal ini dapat dilihat dari nilai $\mathrm{t}_{\text {hitung }}=3,87$ dan $\mathrm{t}_{\text {table }}=2,04$ pada taraf signifikan $\alpha=0,05$, sehingga disimpulkan. Bahwa $\mathrm{t}_{\text {hitung }}>\mathrm{t}$ table.

Penelitian ini tentunya memiliki beberapa kekuarangan seperti data yang masih kurang akurat dikarenakan jumlah populasi yang terbatas. Untuk itu, peneliti menyarankan pada penelitian selanjutnya agar populasi dibuat lebih besar paling tidak mencakup 1 satuan pendidikan.

Hasil penelitian ini dapat dijadikan sebagai bahan perbandingan dan rujukan, untuk mencari media lain atau metode lain yang dapat lebih meningkatkan pemahaman konsep fisika.

Heinich, R. Dkk (1993). Instructional Media (And the new technologies of Instruction). New York: Memillan Publishong.

Indra Sakti, Yuniar Mega Puspasari, dan Eko Risdianto. 2012. Pengaruh Model Pembalajaran Langsung (Direct Instruction) Melalui Media Animasi Berbasis Macromedia Flash terhadap Minat Belajar dan Pemahaman Konsep Fisika Siswa di SMA Plus Negeri 7 Kota Bengkulu. Jurnal Exacta, 10 (1), 1-10.

Nurgiyantoro, Burhan. (2010). Teori pengkajian fiksi, Yogyakarta: Gajah Mada University Press.

Safei. Muh.(2011). Media Pembelajaran. Makassar. Alauddin University Press.

Sigit Widigdo Prayogo, Basyirun, dan Winarno Dwi Rahardjo. 2012. Keefektifan Penggunaan Media Animasi Macromedia Flash pada Materi Kompresor. ASEJ, 1(1), 33-37. 
Karst : Jurnal Pendidikan Fisika dan Terapannya Volume 3 | Nomor 2 | 53 p-ISSN: 2622-9641 e-ISSN: 2655-1276

Siregar, Syofian. 2012. Statistik Parametrik Untuk Penelitian Kuantitatif. Jakarta Remaja Rosdakarya.

Sugiyono, 2011. Metode Penelitian Pendidikan (Pendekatan Kuantitatif, Kualitatif dan R\&D).

Sugiyono, 2012. Metode Penelitian Kuantitatif Kualitatif dan $R \& B$. Bandung: Alfabeta.

Susanto, Ahmad. (2013). Teori Belajar dan Pembelajaran di Sekolah Dasa. Jakarta. Kencana Prenada Media Group. 